\title{
Effect of cut-type on quality of minimally processed papaya
}

\author{
A Carla SJ Argañosa, M Filomena J Raposo, Paula CM Teixeira and \\ Alcina MMB Morais*
}

Escola Superior de Biotecnologia da Universidade Católica Portuguesa, Rua Dr. António Bernardino de Almeida, 4200-072 Porto, Portugal

Keywords: papaya; cut-type; firmness; vitamin C; microbiology; sensory analysis

\begin{abstract}
BACKGROUND: This research was undertaken to study the effects of different cut-types (cube, parallelepiped, cylinder and sphere) on the quality and shelf-life of papaya cv. Sunrise Solo. Physicochemical analyses were carried out during 10 days of storage at $4^{\circ} \mathrm{C}$ to determine colour, firmness, $\mathrm{pH}$, titratable acidity, total soluble solids, weight loss and vitamin $\mathrm{C}$ content. Microbiological analysis and sensory evaluation were also performed.
\end{abstract}

RESULTS: Papaya spheres $(1.55 \mathrm{~cm}$ radius) presented the most favourable physicochemical and microbiological properties (smaller changes in colour parameters $L^{*}, a^{*}, b^{*}$, chroma and hue angle, firmer texture, lower increase in $\mathbf{p H}$, higher titratable acidity, almost constant total soluble solids, reduced weight loss, high vitamin $\mathrm{C}$ content and lower microbial loads) and sensory characteristics on day 10 , while papaya cubes $(1.4 \mathrm{~cm}$ side) proved to be the least acceptable.

CONCLUSION: The results of physicochemical, microbiological and sensory analyses performed on different cuttypes of papaya indicated acceptable fresh-cut produce during 10 days of storage at $4{ }^{\circ} \mathrm{C}$. The potential shelf-life at $4^{\circ} \mathrm{C}$ is therefore 10 days, provided that no contamination occurs in the postharvest period and during minimal processing operations.

\section{Introduction}

Operations involved in the preparation of fresh-cut products are expected to induce a rapid enzymatic depletion of natural antioxidants as a response to injury. ${ }^{1}$ For example, retention of ascorbic acid is dependent on tissue integrity. ${ }^{2}$ Cut tissues have lower barriers to gas diffusion as a result of faster deterioration and increased respiration activity compared with intact commodities. ${ }^{3}$ Freshcut tropical fruits, including papaya, were found to be of unacceptable quality after only 2 days of storage at $4{ }^{\circ} \mathrm{C}$, primarily owing to tissue softening. ${ }^{4,5}$

The use of fresh-cut papaya in food service institutions is very limited owing to the many technical problems involved in maintaining its quality and microbiological safety during storage. ${ }^{6}$ A recent study by Rivera-Lopez et al. ${ }^{7}$ determined the effects of cutting shape (cubes or slices) and storage temperature $\left(5,10\right.$ or $\left.20^{\circ} \mathrm{C}\right)$ on the overall quality of freshcut papaya. Parameters such as $\mathrm{CO}_{2}$ production, colour, firmness, total soluble solids, weight loss, sensory quality, ascorbic acid content, $\beta$-carotene and antioxidant capacity were evaluated during storage. In addition, Teixeira $e t$ al. ${ }^{8}$ studied the effects of cutting dimensions $(2.5 \mathrm{~cm} \times 2.5 \mathrm{~cm}$ vs $2.5 \mathrm{~cm} \times 5.0 \mathrm{~cm})$ and storage temperature $\left(3,6\right.$ or $\left.9^{\circ} \mathrm{C}\right)$ on the atmospheric modification rate and chemical characteristics of 'Formosa' fresh-cut papaya chunks packed in $500 \mathrm{~mL}$ plastic cups.

According to Watada, ${ }^{9}$ cutting of produce results in a large surface area being exposed to the air without any skin for protection against water loss and attack by micro-organisms. ${ }^{10}$ Different shapes of cut papaya already studied include cubes, slices, cylinders, halves and chunks. ${ }^{4,7,8,11,12}$ The surface area/volume ratio of a commodity is a relevant factor influencing evaporation. ${ }^{13}$

Ripening is an important process directly related to papaya quality. Chonhenchob and Singh ${ }^{14}$ and Karakurt and Huber ${ }^{15}$ found that papaya is a fruit that shows a rapid decrease in firmness after cutting. This may be due to a wound-induced increase in the activity of enzymes targeting cell walls and membranes contributing to the rapid deterioration of fresh-cut papaya (as compared with intact fruits stored under the same conditions). The rate of softening after processing depends on many factors related to the product and to the processing and storage conditions. ${ }^{16}$ The stage of maturity of the fruit at cutting is of particular importance, since it affects post-cutting quality and shelf-life. Peleg and GomezBrito $^{17}$ suggested that grading of the state of maturity 
of papaya should be based on three parameters, namely total soluble solids, textural strength and internal colour. Paull and Chen ${ }^{5}$ determined the stage of papaya suitable for minimal processing and the effect of processing on the physiology of the halved fruit. They found that papaya fruit with $55-80 \%$ skin yellowing and less than $50 \mathrm{~N}$ flesh firmness was suitable for minimal processing when combined with a low storage temperature $\left(4^{\circ} \mathrm{C}\right)$ to inhibit ethylene production and respiration. Low temperature reduces respiration, inhibits microbial growth and retards metabolic activity, ripening and senescence. ${ }^{18}$ Minimal processing may increase microbial spoilage of fruits through transfer of skin microflora to the fruit flesh, where micro-organisms can grow rapidly upon exposure to nutrient juices. Recommended tests for assessment of sanitation and manufacturing practices for fruits are enumeration of yeasts and moulds and enumeration of lactic acid bacteria. ${ }^{19}$ Coliforms are part of the normal microflora of fruits and processing lines. ${ }^{4}$ Lowering the temperature reduces microbial proliferation in minimal processing of fruits and vegetables. O'Connor-Shaw et al. ${ }^{4}$ reported that temperatures higher than $4^{\circ} \mathrm{C}$ enhance microbial growth in minimally processed honeydew melon, papaya and pineapple.

The main objective of this research was to determine the effects of different cut-types (cube, parallelepiped, cylinder and sphere) on the quality and shelflife of papaya cv. Sunrise Solo stored at $4^{\circ} \mathrm{C}$. Physicochemical, microbiological and sensory analyses were performed on the different papaya cut-types. Minimal processing of fresh-cut papaya combined with low-temperature storage will hopefully boost the prospective market for this product.

\section{Experimental}

\section{Plant material}

Papayas (cv. Sunrise Solo) grown and harvested in Brazil were imported (air-shipped) by (1) Ercilia $M$ Santos Carneiro and Frias, LDA and (2) Paula \& Amaro, LDA located in Mercado Abastecedor do Porto (MAP), Porto, Portugal. Fruit acquisition was based on visual and colour characteristics $(70-80 \%$ skin yellowness, 3/4 ripe). The papayas were stored at $20^{\circ} \mathrm{C}$ and $50 \%$ relative humidity $(\mathrm{RH})$ overnight before being used in the experiments. Each experiment was performed 5 days after harvest and duplicated after a 1 month interval.

\section{Sample preparation and storage conditions}

Following transfer to the Plant Biotechnology Laboratory of Centro de Biotecnologia e Química Fina (CBQF), Escola Superior de Biotecnologia, Universidade Católica Portuguesa, the fruits were washed first with tap water and then with chlorinated water $\left(0.1 \mathrm{~g} \mathrm{~L}^{-1}\right)$ for $5 \mathrm{~min} .{ }^{20}$ The excess water remaining on the surface of the fruits was dried off with paper towels. The papayas were peeled, deseeded and cut into various shapes (cube, parallelepiped, cylinder and sphere) using a sharp, sterilised knife. Table 1 shows the dimensions of the different papaya cut-types (preformed templates were used) and their corresponding surface areas and surface area/volume $(A / V)$ ratios. The sphere dimensions varied (whole $v s$ half) depending on the size of papaya acquired in MAP. The length of parallelepipeds was adjusted to result in almost the same $A / V$ ratio as that of cylinders. All samples were then placed in rigid plastic containers.

Three replicates per cut-type, per day and per type of analysis were prepared and stored at $4{ }^{\circ} \mathrm{C}$ and $60 \%$ $\mathrm{RH}$ for 10 days.

\section{Quality evaluation}

The fresh-cut papaya cubes, parallelepipeds, cylinders and spheres were examined separately for colour, texture, $\mathrm{pH}$, titratable acidity, total soluble solids, weight loss and L-ascorbic acid content during storage at $4{ }^{\circ} \mathrm{C}$ and $60 \% \mathrm{RH}$. Microbial and sensory analyses were subsequently performed on days 1, 3, 8 and 10 and days 8 and 10 respectively. Three replicates per cut-type, per day and per type of analysis were performed. Each replicate was in a plastic container covered with a lid but not hermetically sealed in order that the atmosphere inside the container was normal atmosphere.

\section{Colour assessment}

Sample surface colour was measured using a handheld Minolta CR-300 tristimulus reflectance colorimeter (Minolta Corp., Ramsey, NJ, USA) and expressed in terms of the CIE $L^{*}, a^{*}, b^{*}$ uniform colour space, where $L^{*}$ represents lightness, $a^{*}$ represents chromaticity on a green $(-)$ to red $(+)$ axis and $b^{*}$ represents chromaticity on a blue $(-)$ to yellow $(+)$ axis. ${ }^{21}$ Chroma $(C)$ was calculated using the formula $C=\left(a^{*^{2}}+b^{*^{2}}\right)^{1 / 2}$. Hue angle $(H)$ was determined as $H=\tan ^{-1}\left(b^{*} / a^{*}\right)$; it ranges from $H=0^{\circ}$ on the $+a^{*}$ axis (red colour) to $H=90^{\circ}$ on the $+b^{*}$ axis (yellow colour).

A total of ten colour measurements were performed on each piece of papaya cut-type. Three pieces were evaluated per replicate.

\section{Firmness measurement}

Texture was measured using an Instron 4501 universal testing instrument (Instron Corp., Canton, OH,

Table 1. Dimensions of fresh-cut papaya pieces and their corresponding surface area/volume $(A / V)$ ratios

\begin{tabular}{lcccc}
\hline Parameter & Cube & $\begin{array}{c}\text { Parallel- } \\
\text { epiped }\end{array}$ & Cylinder & $\begin{array}{c}\text { Sphere } \\
\text { (half-sphere) }\end{array}$ \\
\hline Side $(\mathrm{cm})$ & 1.4 & & & \\
Length $(\mathrm{cm})$ & & 2.0 & 1.8 & \\
Width (cm) & 1.4 & & \\
Height (cm) & 1.4 & & \\
Radius (cm) & & & 0.75 & 1.55 \\
Surface area $\left(\mathrm{cm}^{2}\right)$ & 11.8 & 15.1 & 12.0 & $30.2(22.6)$ \\
A $V$ ratio $\left(\mathrm{cm}^{2}\right)$ & 4.3 & 3.9 & 3.8 & $1.9(2.9)$ \\
\hline
\end{tabular}


USA) with a $5 \mathrm{~kg}$ load cell at a crosshead speed of $10 \mathrm{~mm} \mathrm{~min}^{-1}$. A $2 \mathrm{~mm}$ diameter cylindrical probe was employed. Texture was expressed as the resistance (firmness, $\mathrm{N}$ ) of the fresh-cut papaya flesh to deformation by the probe. Three punctures were performed per replicate.

\section{$\mathrm{pH}$}

Each replicate $(10 \mathrm{~g})$ was homogenised with deionised water $(100 \mathrm{~mL})$ in a $250 \mathrm{~mL}$ beaker using an UltraTurrax T25 (Janke and Kunkel, IKA-Labortechnik, Breisgau, Germany). The $\mathrm{pH}$ of the homogenised solution was measured with a Crison MicropH 2001 potentiometer (Crison Instruments, SA, Barcelona, Spain). The $\mathrm{pH}$ electrode had previously been calibrated using standard solutions of $\mathrm{pH} 4.0$ and 7.0.

\section{Titratable acidity}

Each sample (10 g) was homogenised with deionised water $(100 \mathrm{~mL})$ in a $250 \mathrm{~mL}$ beaker using an UltraTurrax T25 (Janke and Kunkel, IKA-Labortechnik). The solution was titrated with $0.05 \mathrm{~mol} \mathrm{~L}^{-1} \mathrm{NaOH}$ solution until a $\mathrm{pH}$ value of 8.3 was reached. A combined electrode of $\mathrm{pH}$ Ingold U402 57/120 and a Crison MicropH 2001 potentiometer (Crison Instruments, SA) was used. Titratable acidity was expressed as mg citric acid per $100 \mathrm{~g}$ fresh papaya.

\section{Total soluble solids}

Papaya samples were crushed manually with a mortar and pestle to extract the juice. Total soluble solids were determined using an Atago ATC1 hand-held refractometer (Atago Co., Ltd, Tokyo, Japan).

\section{Weight loss}

Three pieces from each cut-type were taken for L-ascorbic acid determination. Different amounts (cube, 2.0-2.5 g; parallelepiped; $4.0-4.5 \mathrm{~g}$; cylinder, $3.5-4.5 \mathrm{~g}$; sphere, $9-10 \mathrm{~g}$ ) of each sample were weighed in tared glass dishes using a basic balance (Sartorius, Göttingen, Germany). The dishes were placed in an oven (WTB Binder, Tuttlingen, Germany) at $70^{\circ} \mathrm{C}$ for $48 \mathrm{~h}$ and then weighed again. Moisture content $\left(\mathrm{g} \mathrm{kg}^{-1}\right)$ was calculated as [(initial weight of dish with sample - weight of dish with sample after drying)/initial weight of dish with sample] $\times 1000$. Weight loss $(\%)$ was calculated as $100-\left(100 \times \mathrm{DM}_{0} / \mathrm{DM}\right)$, where $\mathrm{DM}_{0}\left(\mathrm{~g} \mathrm{~kg}^{-1}\right)$ is the dry matter content on day 0 and DM $\left(\mathrm{g} \mathrm{kg}^{-1}\right)$ is the dry matter content on subsequent days of analysis.

\section{$L$-Ascorbic acid}

This assay was performed according to the manual included in the L-ascorbic acid (L-AA) determination test kit (Number 409677 035, Boehringer Mannheim, Mannheim, Germany). In order to ensure that the loss of L-AA was minimal, all procedures were carried out in an ice bath and with aluminium foil covering the goblets and funnel. Three replicates from each cut-type were analysed. A pulp sample of $2.5 \mathrm{~g}$ was homogenised (Ultra-Turrax T25, Janke and Kunkel, IKA-Labortechnik) with a small amount of metaphosphoric acid. The homogenised sample was then made up to a volume of $25 \mathrm{~mL}$ with metaphosphoric acid $\left(15 \mathrm{~g} \mathrm{~L}^{-1}\right)$. The papaya solution was filtered to obtain a clear extract, as a turbid extract would interfere with spectrophotometric measurements. The $\mathrm{pH}$ of this extract was adjusted to 3.5-4.0 using $10 \mathrm{~mol} \mathrm{~L}^{-1} \mathrm{KOH}$ solution and a $\mathrm{pH}$ electrode (Crison MicropH 2001, Crison Instruments, SA) previously calibrated with buffer solutions of $\mathrm{pH}$ 4.0 and 7.0 .

Absorbances were measured at $578 \mathrm{~nm}$ using a Shimadzu 1601 UV-visible spectrophotometer (Shimadzu, Kyoto, Japan) with deionised water as blank.

L-AA content was expressed as mg L-AA per $100 \mathrm{~g}$ fresh weight and also, by dividing the amount of LAA (mg L-AA per $100 \mathrm{~g}$ papaya) by the DM content (g DM g ${ }^{-1}$ papaya), as mg L-AA per $100 \mathrm{~g}$ dry weight.

\section{Microbiology}

A $10 \mathrm{~g}$ sample of each cut-type was placed in a bag, diluted with $90 \mathrm{~mL}$ of sterile $\mathrm{NaCl}$ solution and homogenised in a stomacher 400 Circulator (Seward, Thetford, Norfolk, UK) for $30 \mathrm{~s}$. Using a sterilised pipette, the resultant slurry was plated onto plate count agar (Merck, Darmstadt, Germany), de Man-Rogosa-Sharpe agar (Merck), violet red bile agar (Merck) and rose bengal chloramphenicol agar base (Oxoid Ltd, Basingstoke, UK) supplemented with $5 \mathrm{~mL}$ of chlortetracycline (Merck). After incubation for $24 \mathrm{~h}$ (faecal coliforms), $72 \mathrm{~h}$ (total microorganisms and lactic acid bacteria) and 5 days (yeasts and moulds) at 44,30 and $25^{\circ} \mathrm{C}$ respectively, manual plate counts of total micro-organisms, ${ }^{22}$ yeasts and moulds, ${ }^{23}$ lactic acid bacteria ${ }^{24}$ and faecal coliforms ${ }^{25}$ were performed and reported as log colony-forming units (CFU) $\mathrm{g}^{-1}$. Microbiological analysis was performed only on days $1,3,8$ and 10 of storage at $4{ }^{\circ} \mathrm{C}$.

\section{Sensory analysis}

Following microbiological analysis, sensory evaluation of fresh-cut papaya was performed according to Rocha et $a l .{ }^{26}$ by 12 or 13 trained panellists on samples that had been cut into cubes, parallelepipeds, cylinders and spheres and stored at $4{ }^{\circ} \mathrm{C}$. Sensory analysis was performed only on days 8 and 10 of storage. The parameters evaluated were global appreciation, general appearance, odour, texture and flavour. The following scale was used for scoring these attributes: 1 , very bad; 3 , neither good nor bad; 5 , very good.

\section{Statistical analysis}

Data were analysed using SPSS for Windows Version 11.5 .0 (SPSS Inc., Chicago, IL, USA). Treatment differences were tested by one-way analysis of variance (ANOVA) and least square difference (LSD) 
comparison $(P<0.05)$. All differences mentioned were significant at $P<0.05$ unless stated otherwise.

\section{Results and discussion}

\section{Colour}

Papaya spheres showed the highest and papaya cylinders the lowest lightness $\left(L^{*}\right)$ values during 10 days of storage at $4{ }^{\circ} \mathrm{C}$ (Fig. 1 ), though the differences were not significant throughout all storage.

Papaya spheres also had high chromaticity $\left(a^{*}\right.$ and $\left.b^{*}\right)$ values throughout storage, showing the highest $a^{*}$ values on days 0,2 and 4 and the highest $b^{*}$ values on days $0,2,4$ and 7 (Table 2). The lowest $a^{*}$ values were observed for papaya cylinders.

Similarly, the chroma $(C)$ values of papaya spheres were highest throughout storage, except on day
10 (Table 2). In addition, papaya spheres exhibited steady decreases in $C$ value with increasing storage time, whereas the other three cut-types showed inconsistent decreases and/or increases. Papaya cylinders had the lowest $C$ values throughout storage.

Papaya cylinders generally presented the highest and papaya parallelepipeds the lowest hue angle $(H)$ values throughout storage (Table 2 ). The difference in surface area between these two cut-types (cylinder, $12.0 \mathrm{~cm}^{2}$; parallelepiped, $15.1 \mathrm{~cm}^{2}$ ) may have contributed to the differences in $H$ value. Meanwhile, the $H$ values of papaya cylinders and spheres showed relative increases on days 2,4 and 7 . In connection with this, Chauhan et al. ${ }^{20}$ reported that the ratio of $a^{*}$ and $b^{*}$ values in pretreated papaya slices stored for 60 days at $6^{\circ} \mathrm{C}$ also showed an increasing trend, like $L^{*}$, indicating less redness and more yellowness.

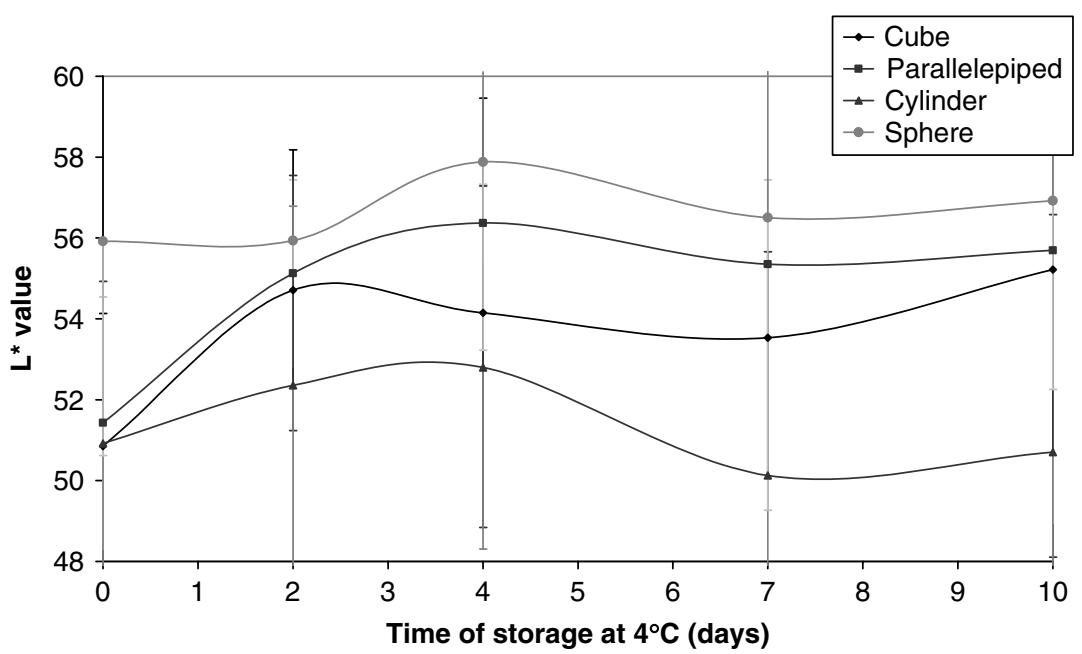

Figure 1. $L^{*}$ values of different shapes of fresh-cut papaya stored at $4{ }^{\circ} \mathrm{C}$.

Table 2. Colour parameters $a^{*}, b^{*}$, chroma and hue angle of fresh-cut papaya stored at $4{ }^{\circ} \mathrm{C}$

\begin{tabular}{|c|c|c|c|c|c|}
\hline Cut-type & Day 0 & Day 2 & Day 4 & Day 7 & Day 10 \\
\hline \multicolumn{6}{|l|}{$a^{*}$ value } \\
\hline Cube & $14.29 \pm 1.50 b$ & $15.06 \pm 0.85 a b$ & $15.83 \pm 1.79 a b$ & $13.96 \pm 2.60 a$ & $14.88 \pm 1.89 a$ \\
\hline Parallelepiped & $13.80 \pm 1.68 b$ & $16.48 \pm 2.33 a b$ & $14.98 \pm 1.19 a b$ & $15.64 \pm 2.36 a$ & $13.50 \pm 2.38 a$ \\
\hline Cylinder & $14.31 \pm 1.43 b$ & $12.90 \pm 1.98 b$ & $12.69 \pm 2.37 b$ & $9.92 \pm 2.66 b$ & $10.27 \pm 2.49 b$ \\
\hline Sphere & $15.72 \pm 3.30 a$ & $17.71 \pm 0.93 a$ & $16.09 \pm 4.20 a$ & $14.48 \pm 4.45 a$ & $13.18 \pm 3.82 a$ \\
\hline \multicolumn{6}{|l|}{$b^{*}$ value } \\
\hline Cube & $35.0 \pm 2.30 b$ & $41.38 \pm 3.28 a b$ & $39.04 \pm 5.44 b$ & $37.97 \pm 5.72 b$ & $42.52 \pm 6.52 a$ \\
\hline Parallelepiped & $34.89 \pm 4.93 b$ & $38.45 \pm 1.64 \mathrm{bc}$ & $37.64 \pm 2.10 b$ & $39.13 \pm 2.49 a$ & $37.67 \pm 6.55 \mathrm{ab}$ \\
\hline Cylinder & $37.57 \pm 4.19 b$ & $37.44 \pm 5.40 c$ & $38.00 \pm 5.79 b$ & $33.30 \pm 5.16 b$ & $33.90 \pm 6.58 b$ \\
\hline Sphere & $44.21 \pm 3.70 a$ & $43.30 \pm 1.59 a$ & $42.82 \pm 3.59 a$ & $40.23 \pm 6.06 a$ & $39.30 \pm 5.89 a$ \\
\hline \multicolumn{6}{|l|}{ Chroma } \\
\hline Cube & $37.83 \pm 2.13 b$ & $44.04 \pm 3.24 a$ & $42.15 \pm 5.54 a b$ & $40.46 \pm 6.22 b$ & $45.08 \pm 6.51 a$ \\
\hline Parallelepiped & $36.04 \pm 3.69 b$ & $41.87 \pm 2.03 a b$ & $40.51 \pm 2.33 b$ & $42.16 \pm 3.16 a$ & $40.04 \pm 6.86 \mathrm{ab}$ \\
\hline Cylinder & $40.22 \pm 4.23 b$ & $39.61 \pm 5.66 b$ & $40.15 \pm 5.57 b$ & $34.77 \pm 5.64 b$ & $35.45 \pm 6.84 b$ \\
\hline Sphere & $47.02 \pm 3.76 a$ & $46.77 \pm 1.80 a$ & $45.92 \pm 3.52 a$ & $42.95 \pm 6.17 a$ & $41.54 \pm 6.36 a b$ \\
\hline \multicolumn{6}{|l|}{ Hue angle $\left(^{\circ}\right)$} \\
\hline Cube & $67.83 \pm 2.69 b$ & $70.03 \pm 1.27 a$ & $67.81 \pm 1.97 \mathrm{~b}$ & $69.90 \pm 1.33 b$ & $70.47 \pm 2.68 b$ \\
\hline Parallelepiped & $67.07 \pm 3.38 \mathrm{ab}$ & $66.94 \pm 2.79 b$ & $68.32 \pm 0.92 b$ & $68.31 \pm 1.94 b$ & $70.22 \pm 1.82 b$ \\
\hline Cylinder & $69.14 \pm 1.87 a b$ & $71.02 \pm 1.41 \mathrm{a}$ & $71.23 \pm 4.23 a$ & $73.67 \pm 2.37 a$ & $73.15 \pm 2.75 a$ \\
\hline Sphere & $70.5 \pm 3.94 a$ & $67.83 \pm 0.48 b$ & $69.39 \pm 5.27 a b$ & $70.10 \pm 5.65 b$ & $71.76 \pm 4.54 a b$ \\
\hline
\end{tabular}

For each parameter, values with different letters in the same column are significantly different $(P<0.05)$. 
Rivera-Lopez et al. ${ }^{7}$ reported initial hue angles of $53 \pm 2.5^{\circ}$, lower than the $H$ values obtained in the present study. Their results showed that freshcut papaya cubes and slices retained their natural yellow/red colour during 18 days of storage.

Sphere-shaped papaya tended to show the highest $L^{*}, a^{*}, b^{*}$ and $C$ values. Compared with discolouration events in other crops, such as white blush in carrots and secondary browning in apples, ${ }^{27}$ the results of the present colour evaluation of all papaya cut-types did not show severe browning. In terms of global appreciation the sensory panellists preferred sphereshaped papaya on day 8 of storage (see Table 6). Heterogeneity of the whole papaya samples used during the study might have contributed to the variations in colour among samples. Lastly, the colour parameters of all cut-types did not change drastically, so colour was not a relevant factor in assessing the quality of fresh-cut papaya in the present study.

\section{Texture}

The firmness values of papaya cylinders were highest among all cut-types during 10 days of storage at $4{ }^{\circ} \mathrm{C}$ (Table 3). However, this may be due to the fact that the firmness of papaya cylinders was already highest at the beginning (day 0) of storage. Papaya spheres had the lowest firmness values on days 0 and 2 , but after
4 days of storage they showed the same firmness as cubes and parallepipeds, and their decrease in firmness was lowest after 10 days. The firmness of papaya spheres decreased significantly by $35 \%$, cylinders by $41 \%$, parallelepipeds by $48 \%$ and cubes by $58 \%$ after 10 days of storage.

The surface area/volume $(A / V)$ ratio of a cube is 1.5-2 times higher than that of the corresponding sphere, resulting in greater firmness loss of cubes after 10 days of storage. Paull ${ }^{13}$ reported that storage temperature may significantly influence fruit firmness and that firmness loss increases with storage time. According to Karakurt and Huber, ${ }^{15}$ the firmness of fresh-cut papaya pieces (approximately $7 \mathrm{~cm} \times 5 \mathrm{~cm} \times$ $3 \mathrm{~cm}$ ) decreased by about $36 \%$ after only 2 days and continued to decline steadily throughout storage at $5{ }^{\circ} \mathrm{C}$. Similar trends were reported by Rivera-Lopez et al., ${ }^{7}$ who found that the firmness of papaya slices decreased significantly $(P \leq 0.05$ ) by $65 \%$ (from 9.8 to $3.2 \mathrm{~N}$ ) while that of papaya cubes decreased by $57 \%$ (from 7.5 to $3.2 \mathrm{~N}$ ) after 16 days of storage at $5{ }^{\circ} \mathrm{C}$. Differences between the initial firmness values in the present study and those reported in the literature may have been due to the use of different cylindrical probes to evaluate firmness.

Watada and $\mathrm{Qi}^{28}$ showed that water loss in freshcut fruits and vegetables is rapid owing to damaged

Table 3. Firmness, $\mathrm{pH}$, titratable acidity, total soluble solids, moisture content and weight loss of fresh-cut papaya stored at $4{ }^{\circ} \mathrm{C}$

\begin{tabular}{|c|c|c|c|c|c|}
\hline Cut-type & Day 0 & Day 2 & Day 4 & Day 7 & Day 10 \\
\hline \multicolumn{6}{|l|}{ Firmness (N) } \\
\hline Cube & $0.86 \pm 0.06 b$ & $0.70 \pm 0.10 b$ & $0.60 \pm 0.07 b$ & $0.51 \pm 0.05 b$ & $0.36 \pm 0.08 c$ \\
\hline Parallelepiped & $0.82 \pm 0.08 b$ & $0.72 \pm 0.08 b$ & $0.59 \pm 0.08 b$ & $0.52 \pm 0.07 b$ & $0.43 \pm 0.08 b$ \\
\hline Cylinder & $0.97 \pm 0.08 a$ & $0.89 \pm 0.12 a$ & $0.76 \pm 0.09 a$ & $0.64 \pm 0.11 a$ & $0.57 \pm 0.11 a$ \\
\hline Sphere & $0.72 \pm 0.06 c$ & $0.63 \pm 0.06 c$ & $0.55 \pm 0.08 b$ & $0.52 \pm 0.07 b$ & $0.47 \pm 0.08 b$ \\
\hline \multicolumn{6}{|l|}{$\mathrm{pH}$} \\
\hline Cube & $5.44 \pm 0.02 c$ & $5.46 \pm 0.01 c$ & $5.52 \pm 0.03 c$ & $5.59 \pm 0.02 b$ & $5.72 \pm 0.02 a$ \\
\hline Parallelepiped & $5.52 \pm 0.02 b$ & $5.54 \pm 0.03 b$ & $5.56 \pm 0.03 b$ & $5.56 \pm 0.03 b$ & $5.61 \pm 0.01 c$ \\
\hline Cylinder & $5.55 \pm 0.03 b$ & $5.56 \pm 0.02 b$ & $5.58 \pm 0.03 b$ & $5.58 \pm 0.02 b$ & $5.67 \pm 0.02 b$ \\
\hline Sphere & $5.61 \pm 0.01 a$ & $5.60 \pm 0.02 a$ & $5.64 \pm 0.04 a$ & $5.63 \pm 0.02 a$ & $5.68 \pm 0.02 b$ \\
\hline \multicolumn{6}{|c|}{ Titratable acidity (mg citric acid per $100 \mathrm{~g}$ fresh weight) } \\
\hline Cube & $84.74 \pm 0.92 a$ & $83.71 \pm 1.24 a$ & $82.64 \pm 0.62 a$ & $79.24 \pm 0.99 a$ & $74.38 \pm 0.72 b$ \\
\hline Parallelepiped & $79.22 \pm 0.50 b$ & $78.63 \pm 0.70 b$ & $78.58 \pm 0.68 b$ & $78.30 \pm 0.97 a$ & $78.02 \pm 0.58 a$ \\
\hline Cylinder & $79.82 \pm 1.01 b$ & $78.85 \pm 0.97 b$ & $78.12 \pm 0.37 b$ & $78.62 \pm 0.77 a$ & $77.74 \pm 0.32 a$ \\
\hline Sphere & $76.81 \pm 0.63 c$ & $76.89 \pm 0.87 c$ & $75.54 \pm 1.00 c$ & $76.08 \pm 0.72 b$ & $75.57 \pm 0.33 b$ \\
\hline \multicolumn{6}{|c|}{ Total soluble solids ( ${ }^{\circ}$ Brix) } \\
\hline Cube & $13.1 \pm 0.1 b$ & $12.9 \pm 0.3 b$ & $13.8 \pm 0.2 \mathrm{a}$ & $14.5 \pm 0.1 \mathrm{a}$ & $13.7 \pm 0.1 \mathrm{a}$ \\
\hline Parallelepiped & $12.8 \pm 0.2 c$ & $13.1 \pm 0.1 \mathrm{ab}$ & $12.2 \pm 0.5 c$ & $13.5 \pm 0.1 b$ & $13.6 \pm 0.2 a$ \\
\hline Cylinder & $13.3 \pm 0.1 \mathrm{ab}$ & $12.1 \pm 0.2 c$ & $13.7 \pm 0.1 \mathrm{a}$ & $14.6 \pm 0.2 \mathrm{a}$ & $12.9 \pm 0.1 b$ \\
\hline Sphere & $13.5 \pm 0.1 a$ & $13.3 \pm 0.3 a$ & $13.2 \pm 0.5 b$ & $12.5 \pm 0.1 \mathrm{c}$ & $12.9 \pm 0.1 b$ \\
\hline \multicolumn{6}{|c|}{ Moisture content $\left(\mathrm{g} \mathrm{kg}^{-1}\right)$} \\
\hline Cube & $858.5 \pm 5.5 a$ & $852.5 \pm 5.3 a$ & $847.0 \pm 5.1 \mathrm{ab}$ & $842.5 \pm 6.7 b$ & $837.3 \pm 5.9 b$ \\
\hline Parallelepiped & $853.3 \pm 2.4 a$ & $847.8 \pm 2.7 a$ & $843.6 \pm 3.3 b$ & $841.2 \pm 2.7 b$ & $837.5 \pm 1.6 b$ \\
\hline Cylinder & $860.0 \pm 7.3 a$ & $855.6 \pm 6.7 a$ & $851.4 \pm 7.1 \mathrm{ab}$ & $849.2 \pm 7.9 a b$ & $846.8 \pm 7.1 \mathrm{a}$ \\
\hline Sphere & $857.8 \pm 4.5 a$ & $855.4 \pm 4.2 \mathrm{a}$ & $854.5 \pm 4.0 \mathrm{a}$ & $852.0 \pm 3.5 a$ & $850.9 \pm 5.3 a$ \\
\hline \multicolumn{6}{|l|}{ Weight loss (\%) } \\
\hline Cube & 0 & $2.05 \pm 0.13 b$ & $5.74 \pm 0.02 b$ & $7.92 \pm 0.84 a b$ & $11.21 \pm 1.1 \mathrm{a}$ \\
\hline Parallelepiped & 0 & $2.61 \pm 0.20 b$ & $5.10 \pm 1.02 b$ & $6.69 \pm 0.16 b$ & $9.69 \pm 0.90 a$ \\
\hline Cylinder & 0 & $5.44 \pm 1.82 a$ & $7.99 \pm 2.80 a$ & $9.69 \pm 2.21 a$ & $10.83 \pm 1.7 \mathrm{a}$ \\
\hline Sphere & 0 & $3.20 \pm 1.24 b$ & $3.80 \pm 0.80 c$ & $5.23 \pm 0.06 c$ & $6.58 \pm 0.43 b$ \\
\hline
\end{tabular}

For each parameter, values with different letters in the same column are significantly different $(P<0.05)$. 
and exposed cuticular and sub-epidermal layers and a lack of protective skin, leading to greater losses in firmness associated with factors such as temperature and storage time. The higher decrease in firmness of cube-shaped papaya compared with other cut-types may be attributable to its relatively high $A / V$ ratio, which resulted in high weight loss as well (Table 3 ).

\section{$\mathrm{pH}$}

Significant increases in $\mathrm{pH}$ value for all papaya cuttypes were observed after 10 days of storage at $4{ }^{\circ} \mathrm{C}$ (Table 3). The lowest $\mathrm{pH}$ increase was $1.3 \%$ for spheres and the highest $5.2 \%$ for cubes.

Since organic acids (predominantly citric and malic acids in papaya) are the substrates of enzymatic reactions during respiration, an increase in $\mathrm{pH}$ is expected during storage. ${ }^{29}$

Papaya cubes presented the lowest $\mathrm{pH}$ among all cut-types on day 0 , but subsequent storage equalised it to that of parallelepipeds and cylinders on day 7 . However, after 10 days of storage the $\mathrm{pH}$ of cubes rose to the highest value (5.72). Meanwhile, similar $\mathrm{pH}$ values for parallelepipeds and cylinders were observed on days $0,2,4$ and 7 , lying between the $\mathrm{pH}$ values of cubes and spheres. This similarity in $\mathrm{pH}$ values may be attributable to their similar $A / V$ ratios (cylinder, $3.8 \mathrm{~cm}^{-1}$; parallelepiped, $3.9 \mathrm{~cm}^{-1}$ ). Low $\mathrm{pH}$ is preferred in fresh-cut fruits because it provides better protection against microbial growth. Although the $\mathrm{pH}$ differences among cut-types in the present study were not very large, they were significant.

Papaya cv. Solo fruits commercialised in four establishments located in Brasilia-Distrito Federal were found to have $\mathrm{pH}$ values varying from 5.20 to 5.71, with higher values being observed in August and September. ${ }^{30}$ The approximate $\mathrm{pH}$ of papaya has been reported as $5.2-6.0 .^{31}$ The initial $\mathrm{pH}$ in the present study was around 5.5 .

However, Chauhan et al. ${ }^{20}$ reported lower $\mathrm{pH}$ values of 4.5-5.0 for papaya pretreated by mild acidification with citric acid. Their study showed that the $\mathrm{pH}$ value decreased significantly $(P<0.05)$ from the original $\mathrm{pH} 5.7-5.8$ of cut papaya during 60 days of storage at $6 \pm 1{ }^{\circ} \mathrm{C}$.

\section{Titratable acidity}

Significant decreases in titratable acidity (TA) were observed for all papaya cut-types during 10 days of storage at $4{ }^{\circ} \mathrm{C}$. However, higher TA values are preferred during storage because they correlate with low $\mathrm{pH}$ values, thereby preventing the early growth of micro-organisms in fresh-cut fruits.

In agreement with the $\mathrm{pH}$ results (Table 3), it was observed that the TA of papaya cubes decreased significantly by $12 \%$ after 10 days (Table 3 ). Parallelepipeds showed the lowest decrease in TA $(1.5 \%)$ during the same time, followed by spheres $(1.6 \%)$. Cubes presented the highest TA values on days 0,2 and 4 , while spheres showed the lowest values on days $0,2,4$ and 7 .
The decrease in TA observed was in agreement with the results of Teixeira et al. ${ }^{8}$ who reported that 'Formosa' papaya chunks $(2.5 \mathrm{~cm} \times 5.0 \mathrm{~cm})$ showed higher TA reduction at 6 and $9^{\circ} \mathrm{C}$ than at $3^{\circ} \mathrm{C}$.

The acid content of papaya is very low and comes from almost equal amounts of citric and malic acids, ${ }^{32}$ the concentrations of which are known to decrease during ripening. ${ }^{33}$

Published TA values for papaya are within the range found in this study. Hernandez et al. ${ }^{34}$ reported a ripe papaya TA value of $72 \pm 8 \mathrm{mg}$ citric acid per $100 \mathrm{~g}$ fruit. The papaya used in their study was harvested at the mature green stage and allowed to ripen at $18^{\circ} \mathrm{C}$, with a total soluble solids content of $12.1 \pm 1.1^{\circ} \mathrm{Brix}$, which is very similar to the values obtained in the present study. Meanwhile, Fernandes et al. ${ }^{35}$ reported a fresh papaya TA value of $15 \pm 1 \mathrm{mg}$ citric acid per $100 \mathrm{~g}$ fruit.

\section{Total soluble solids}

Significant differences in total soluble solids (TSS) were observed on day 0 among papaya cut-types, with parallelepipeds showing the lowest and spheres the highest TSS value (Table 3). Papaya cubes were found to have the highest TSS values on days 4, 7 and 10 , while no specific trend was observed regarding which cut-type had the lowest TSS value after 10 days of storage at $4{ }^{\circ} \mathrm{C}$.

TSS values remained approximately constant throughout storage, but with significant differences among cut-types. The results of the present study are somewhat in contrast with those of Rivera-Lopez et al.,$^{7}$ who found that $3 / 4$ ripe papaya with an initial TSS of $9.5^{\circ}$ Brix showed decreases in TSS in cubes and slices after 18 days of storage at 5,10 and $20^{\circ} \mathrm{C}$. They explained this finding on the assumption that sugars are the first substrates used during respiration.

\section{Moisture content}

No significant differences in moisture content were observed among papaya cut-types during the first 2 days of storage at $4{ }^{\circ} \mathrm{C}$ (Table 3). Papaya cubes showed the highest $(2.5 \%)$ and spheres the lowest $(0.8 \%)$ decrease in moisture content after 10 days of storage.

Spheres and cylinders had the highest moisture contents on days 4 and 7, while parallelepipeds and cubes had the lowest moisture contents on days 4,7 and 10 .

According to Fernandes et al..${ }^{35}$ the average initial moisture content of fresh papaya before osmotic dehydration was $878.3 \mathrm{~g} \mathrm{~kg}^{-1}$, while Hernandez et al. ${ }^{34}$ reported a moisture content of ripened papaya of $900 \pm 30 \mathrm{~g} \mathrm{~kg}^{-1}$. These values are very close to those obtained in the present study. Although the reduction of moisture content to a certain level is one of the main tasks in food preservation, ${ }^{36}$ moisture retention in fresh-cut fruits is desirable for the preservation of fresh-like quality. 


\section{Weight loss}

Papaya cubes showed the highest (11\%) and spheres the lowest $(7 \%)$ weight loss after 10 days of storage at $4{ }^{\circ} \mathrm{C}$ (Table 3 ).

Higher weight loss in cubes would require more force to puncture fresh-cut papaya. The higher decrease in weight of papaya cubes may be attributed to their higher $A / V$ ratio $\left(4.3 \mathrm{~cm}^{-1}\right)$ compared with other cut-types.

Fresh-cut produce has a large surface area without any skin and thus has the potential to lose a substantial amount of weight, particularly at higher temperatures where the vapour pressure deficit is large. ${ }^{37}$

Weight loss results for spheres were in agreement with firmness results only on day 2 : lower weight losses in spheres corresponded to lower decreases in firmness. Higher weight losses in cubes resulted in higher decreases in firmness on days 7 and 10 .

Paull ${ }^{13}$ reported that in many fresh commodity storage studies the deterioration of quality attributes such as appearance and texture was ascribed to water loss.

\section{L-Ascorbic acid content}

No significant differences in L-AA content on a fresh weight basis among papaya cut-types were observed on day 1 of storage at $4^{\circ} \mathrm{C}$ (Table 4 ).

L-AA contents in the present study were slightly lower than those reported by Rivera-Lopez et al. ${ }^{7}$ for $3 / 4$ ripe papaya cubes and slices, which contained $65.47 \mathrm{mg}$ L-AA per $100 \mathrm{~g}$ fresh weight at the beginning of storage. However, Wall ${ }^{38}$ reported that $1 / 8$ ripe Hawaiian papaya cultivars contained $45-55 \mathrm{mg}$ L-AA per $100 \mathrm{~g}$ fresh weight. The L-AA contents of fresh-cut papaya found in the present study were much lower than (less than half) those reported by Hernandez et $a .^{34}$ for mature green papaya ripened at $18^{\circ} \mathrm{C}$ (154 $\pm 17 \mathrm{mg} \mathrm{L-AA}$ per $100 \mathrm{~g}$ fresh weight).

L-AA contents were also calculated on a dry weight basis, because weight losses were very different among samples and therefore L-AA content on a fresh weight basis did not reflect the real content of L-AA. No significant differences in L-AA content on a dry weight basis were noted among different papaya cut-types on day 1 of storage at $4{ }^{\circ} \mathrm{C}$ (Table 4 ). It was only on day 3 that significant differences in L-AA contents of papaya cubes versus cylinders and spheres were observed. These differences were not so obvious on a fresh weight basis.

The L-AA content of papaya cubes on a dry weight basis decreased by $14 \%$, parallelepipeds by $20 \%$, spheres by $21 \%$ and cylinders by $26 \%$ after 10 days of storage.

Alhough the total surface area of papaya cubes $\left(11.8 \mathrm{~cm}^{2}\right)$ was not very different from that of cylinders $\left(12.0 \mathrm{~cm}^{2}\right)$, the decrease in L-AA content of papaya cylinders was almost double that of cubes after 10 days of storage. Higher losses might be expected in papaya cubes, since their $A / V$ ratio $\left(4.3 \mathrm{~cm}^{-1}\right)$ is somewhat higher than that of cylinders $\left(3.8 \mathrm{~cm}^{-1}\right)$.

Differences in L-AA content between fresh and dry weight bases can be attributed to the moisture content evolution of fresh-cut samples during storage. There was no defined correlation between the decrease in L-AA content and each cut-type surface area or $A / V$ ratio for all geometries, though cylinders and parallelepipeds had similar $A / V$ ratios. ArtésHernández et al. ${ }^{39}$ reported that wedges, slices and $1 / 2$ slices of fresh-cut lemon products ('Lisbon') were preserved for a 10 day shelf-life period, with good retention of vitamin $\mathrm{C}$, when kept at $0-5{ }^{\circ} \mathrm{C}$ and protected from water loss by proper packaging with high relative humidity during distribution. In the present study, cube-shaped fresh-cut papaya tended to retain higher L-AA content than other cut-types during the 10 day shelf-life period at $4{ }^{\circ} \mathrm{C}$.

\section{Microbiological analysis}

Total count of micro-organisms

On day 1 of storage at $4^{\circ} \mathrm{C}$, there were significant differences in total counts of micro-organisms on papaya cubes and parallelepipeds compared with those on papaya cylinders and spheres (Table 5). However, there were no differences in total count among all cut-types on day 10 of storage. Total counts on papaya spheres were relatively low up to day 8 but increased during the last 2 days of storage. This might be attributed to the fact that the $A / V$ ratio of papaya spheres $\left(1.9-2.9 \mathrm{~cm}^{-1}\right)$ is the lowest among all cut-types. Total counts of micro-organisms on

Table 4. L-Ascorbic acid (L-AA) content of fresh-cut papaya stored at $4{ }^{\circ} \mathrm{C}$

\begin{tabular}{|c|c|c|c|c|}
\hline Cut-type & Day 1 & Day 3 & Day 6 & Day 9 \\
\hline \multicolumn{5}{|c|}{ mg L-AA per $100 \mathrm{~g}$ fresh weight } \\
\hline Cube & $56.73 \pm 2.23 a$ & $60.24 \pm 0.50 a$ & $58.34 \pm 3.93 a$ & $55.13 \pm 8.51 a$ \\
\hline Parallelepiped & $51.72 \pm 1.26 a$ & $56.62 \pm 3.17 a b$ & $54.02 \pm 2.34 a b$ & $48.32 \pm 1.10 b$ \\
\hline Cylinder & $53.48 \pm 1.81 a$ & $57.32 \pm 2.26 a b$ & $48.56 \pm 7.82 b$ & $43.82 \pm 6.76 b$ \\
\hline Sphere & $52.19 \pm 2.19 a$ & $51.75 \pm 1.27 b$ & $49.90 \pm 4.18 b$ & $48.29 \pm 2.96 b$ \\
\hline \multicolumn{5}{|c|}{ mg L-AA per $100 \mathrm{~g}$ dry weight } \\
\hline Cube & $396.3 \pm 16 a$ & $380.8 \pm 3 a$ & $360.1 \pm 24 a$ & $341.2 \pm 48 a$ \\
\hline Parallelepiped & $381.2 \pm 9 a$ & $376.9 \pm 21 a b$ & $350.4 \pm 15 a b$ & $305.8 \pm 7 a$ \\
\hline Cylinder & $391.9 \pm 13 a$ & $368.7 \pm 7 b$ & $324.2 \pm 52 b$ & $289.5 \pm 45 b$ \\
\hline Sphere & $387.5 \pm 16 a$ & $356.9 \pm 9 b$ & $330.6 \pm 28 a$ & $307.7 \pm 19 a$ \\
\hline
\end{tabular}

For each content, values with different letters in the same column are significantly different $(P<0.05)$. 
Table 5. Counts of total micro-organisms, yeasts and moulds, faecal coliforms and lactic acid bacteria on fresh-cut papaya stored at $4{ }^{\circ} \mathrm{C}$

\begin{tabular}{|c|c|c|c|c|}
\hline Cut-type & Day 1 & Day 3 & Day 8 & Day 10 \\
\hline \multicolumn{5}{|c|}{ Total micro-organisms (CFU g $\left.{ }^{-1}\right)$} \\
\hline Cube & $<30 \times 10 a$ & $<30 \times 10 a$ & $<30 \times 10 a$ & $<30 \times 10 a$ \\
\hline Parallelepiped & $<30 \times 10 a$ & $<30 \times 10 a$ & $<30 \times 10 a$ & $<30 \times 10 a$ \\
\hline Cylinder & $<1.0 \times 10 b$ & $<30 \times 10 a$ & $<30 \times 10 a$ & $<30 \times 10 a$ \\
\hline Sphere & $<1.0 \times 10 b$ & $<1.0 \times 10 b$ & $<1.0 \times 10 b$ & $<30 \times 10 a$ \\
\hline \multicolumn{5}{|c|}{ Yeasts and moulds (CFU g $\left.{ }^{-1}\right)$} \\
\hline Cube & $<1.0 \times 10 \mathrm{a}$ & $1.0 \times 10 \mathrm{a}$ & $1.0 \times 10 a$ & $2.0 \times 10 a$ \\
\hline Parallelepiped & $<1.0 \times 10 a$ & $<1.0 \times 10 b$ & $1.0 \times 10 a$ & $2.0 \times 10 a$ \\
\hline Cylinder & $<1.0 \times 10 a$ & $<1.0 \times 10 b$ & $1.0 \times 10 a$ & $2.0 \times 10 a$ \\
\hline Sphere & $<1.0 \times 10 a$ & $<1.0 \times 10 b$ & $<1.0 \times 10 b$ & $<1.0 \times 10 b$ \\
\hline \multicolumn{5}{|c|}{ Faecal coliforms (CFU g $\left.{ }^{-1}\right)$} \\
\hline Cube & $<1.0 \times 10 a$ & $<1.0 \times 10 a$ & $<1.0 \times 10 a$ & $<15 \times 10 a$ \\
\hline Parallelepiped & $<1.0 \times 10 a$ & $<1.0 \times 10 a$ & $<1.0 \times 10 a$ & $<15 \times 10 a$ \\
\hline Cylinder & $<1.0 \times 10 a$ & $<1.0 \times 10 a$ & $<1.0 \times 10 a$ & $<15 \times 10 a$ \\
\hline Sphere & $<1.0 \times 10 a$ & $<1.0 \times 10 a$ & $<1.0 \times 10 a$ & $<15 \times 10 a$ \\
\hline \multicolumn{5}{|c|}{ Lactic acid bacteria (CFU g $\left.{ }^{-1}\right)$} \\
\hline Cube & $<1.0 \times 10 a$ & $<1.0 \times 10 a$ & $<1.0 \times 10 a$ & $<1.0 \times 10 a$ \\
\hline Parallelepiped & $<1.0 \times 10 a$ & $<1.0 \times 10 a$ & $<1.0 \times 10 a$ & $<1.0 \times 10 a$ \\
\hline Cylinder & $<1.0 \times 10 a$ & $<1.0 \times 10 a$ & $<1.0 \times 10 a$ & $<1.0 \times 10 a$ \\
\hline Sphere & $<1.0 \times 10 a$ & $<1.0 \times 10 a$ & $<1.0 \times 10 a$ & $<1.0 \times 10 a$ \\
\hline
\end{tabular}

For each parameter, values with different letters in the same column are significantly different $(P<0.05)$.

papaya cubes studied by O'Connor-Shaw et al. ${ }^{4}$ were $(2.6-3.3) \times 10^{4} \mathrm{CFU} \mathrm{g}^{-1}$ on day 4 of storage. Jacxsens et al. ${ }^{40}$ reported that the critical limit of total counts of micro-organisms for vegetables is $10^{8} \mathrm{CFU} \mathrm{g}^{-1}$, which is higher than the levels found in the present study.

\section{Yeasts and moulds}

Significant increases in counts of yeasts and moulds were observed on papaya cubes, parallelepipeds and cylinders from day 1 to day 10 of storage at $4{ }^{\circ} \mathrm{C}$ (Table 5). However, there was no effect of papaya cut-type on day 1. Sphere-shaped fresh-cut papaya showed the lowest counts among all cut-types, as no occurrence of yeasts and moulds was observed, in agreement with the results for total counts of microorganisms on days 1,3 and 8 .

All counts were lower than the critical limit for yeasts $\left(10^{5} \mathrm{CFU} \mathrm{g}^{-1}\right)^{41}$ on all days of storage. Chauhan et al. ${ }^{20}$ reported that pretreated papaya slices stored under various modified atmosphere packaging conditions showed zero counts of yeasts and moulds.

\section{Faecal coliforms}

No significant differences in faecal coliform count were observed among cut-types during 10 days of storage at $4{ }^{\circ} \mathrm{C}$ (Table 5). Although O'Connor-Shaw et al. ${ }^{4}$ stated that coliforms are part of the normal microflora of fruits found in the soil, the results of the present study did not reflect this, as careful sample preparation and disinfection were performed. On day 10 of storage, relatively higher counts of faecal coliforms were registered, though still acceptable. ${ }^{41}$

O'Connor-Shaw et al.$^{4}$ reported Enterobacteriaceae counts of $(1.2-1.6) \times 10^{6} \mathrm{CFU} \mathrm{g}^{-1}$ on minimally processed papaya on day 4 of storage at $4{ }^{\circ} \mathrm{C}$, as the authors did not sanitise the fruit prior to processing, though good manufacturing practices were followed. Meanwhile, Chauhan et al. ${ }^{20}$ found that papaya slices pretreated with antimicrobial additives such as sorbate and benzoate and packed in modified atmosphere registered zero coliform counts up to 60 days.

\section{Lactic acid bacteria}

Papaya cut-type had no effect on the growth of lactic acid bacteria, since zero counts were recorded for all cut-types during 10 days of storage at $4{ }^{\circ} \mathrm{C}$ (Table 5). These results agree with the claim by Brackett ${ }^{42}$ that the low $\mathrm{pH}$ of most fruits restricts the microflora to acid-tolerant micro-organisms such as fungi and lactic acid bacteria. O'Connor-Shaw et al. ${ }^{4}$ recorded lactic acid bacteria counts of $(1.8-3.1) \times 10^{3} \mathrm{CFUg}^{-1}$ on papaya cubes after 4 days of storage at $4^{\circ} \mathrm{C}$. According to Jacxsens et al. ${ }^{40}$ the critical limit for lactic acid bacteria on vegetables is $10^{7} \mathrm{CFU} \mathrm{g}^{-1}$, which is again very high compared with the results of the present study.

Minimally processed products with high $\mathrm{pH}(>4.6)$ are considered to be highly perishable when they are not subjected to preservative processes that delay undesirable biological and biochemical changes. ${ }^{43}$ The results of the microbiological evaluation in the present study, however, indicate that storage at $4{ }^{\circ} \mathrm{C}$, associated with disinfection of whole papaya ( $\mathrm{pH} \approx 5.5$ ), can extend the shelf-life of all cut-types studied to 10 days. In relation to this, Teixeira et al. ${ }^{8}$ reported that fresh-cut 'Formosa' papaya chunks, hygienically prepared during processing, also showed low microbial counts $\left(10^{3} \mathrm{CFU} \mathrm{g}^{-1}\right)$ after storage at $9^{\circ} \mathrm{C}$ for 7 days. 


\section{Sensory evaluation}

Most studies on fresh-cut fruits have been concerned with market quality determined objectively and subjectively by colour, sensory and texture measurements as well as by microbiological assays. ${ }^{44}$ The present study included the first microbiological analysis of freshcut papaya stored at $4{ }^{\circ} \mathrm{C}$ for up to 10 days. Since the results were satisfactory (i.e. counts well below acceptable limits), sensory evaluation was carried out on days 8 and 10 of storage.

Sensory studies have been extensively carried out to evaluate the influence of processing and storage conditions on the quality perception of fresh-cut fruits by either trained or untrained judges. ${ }^{45}$ Consumers judge the quality of fresh-cut fruits and vegetables on the basis of appearance and freshness at the time of purchase. Sphere-shaped papaya received the highest score for global appreciation on day 8 (Table 6).

The sensory results indicated that the edible shelflife of all papaya cut-types was 10 days at $4{ }^{\circ} \mathrm{C}$ if the limit of acceptability was set at 3.0. Quality scores ranged between 3.3 and 4.1. There were no significant differences among papaya cut-types in terms of global appreciation, general appearance, odour and flavour on day 10. However, on that day, papaya parallelepipeds were regarded by panellists as having the most acceptable texture, while spheres received the lowest score. These results are not in agreement with the firmness results, as papaya cylinders were found to be most firm and cubes least firm on day 10 (Table 3). Differences in sensory panellists' evaluation could be attributed to the use of different batches of whole papaya. Ergun et al ${ }^{46}$ reported that ripe papaya slices treated with 1-methylcyclopropene and stored at $5^{\circ} \mathrm{C}$ had an edible shelf-life of 6 days as compared with only 2-3 days for control samples.

Papaya cv. Maradol cubes and slices stored at $5{ }^{\circ} \mathrm{C}$ showed good overall quality (score of $4=$ good) until day 10 of storage. ${ }^{7}$ However, O'Connor-Shaw et al. ${ }^{4}$ evaluated the shelf-life of papaya cubes stored at $4{ }^{\circ} \mathrm{C}$ and reported that it was limited to only 2 days owing to unacceptable appearance and bitter flavour.
In addition to maintaining the appearance of produce, low-temperature storage has the benefit of protecting quality attributes such as texture, nutrition, aroma and flavour. ${ }^{13}$ The results of physicochemical, microbiological and sensory analyses performed on the different papaya cut-types in the present study indicated an acceptable minimally processed product during storage at $4{ }^{\circ} \mathrm{C}$ for up to 10 days. Sphere-shaped papaya showed reduced weight loss, lower increase in $\mathrm{pH}$, higher titratable acidity, higher firmness and acceptable microbial and sensory results, making it the best cut-type until day 10 of storage at $4{ }^{\circ} \mathrm{C}$, while cube-shaped papaya was the least acceptable. However, laboratory studies may vary considerably from commercial handling and thereby affect shelflife. Thus quality improvement at all levels of produce handling and recognition that each step or procedure is significant can have a great impact on the minimal processing of fruits and vegetables.

\section{Conclusions}

The effect of different cut-types (cube, parallelepiped, cylinder and sphere) on the quality of papaya cv. Sunrise Solo was determined. The results of physicochemical, microbiological and sensory analyses performed on the different papaya cut-types indicated an acceptable minimally processed product during storage at $4{ }^{\circ} \mathrm{C}$ for up to 10 days.

Colour values did not differ significantly among cuttypes, though papaya spheres $(1.55 \mathrm{~cm}$ radius $)$ tended to show higher $L^{*}, a^{*}$ and $b^{*}$ values and relatively low decreases in $C$ value compared with other cut-types throughout the storage period.

Papaya spheres showed the lowest losses of texture and weight during 10 days of storage at $4{ }^{\circ} \mathrm{C}$, while cubes $(1.4 \mathrm{~cm}$ side) presented the highest losses. Papaya cubes also exhibited the highest $\mathrm{pH}$ increase after 10 days. Papaya spheres and parallelepipeds showed low TA values, while TSS contents did not show a consistent trend, remaining approximately constant.

Table 6. Sensory evaluation of fresh-cut papaya on days 8 and 10 of storage at $4{ }^{\circ} \mathrm{C}$

\begin{tabular}{|c|c|c|c|c|c|}
\hline Cut-type & $\begin{array}{c}\text { Global } \\
\text { appreciation }\end{array}$ & $\begin{array}{c}\text { General } \\
\text { appearance }\end{array}$ & Odour & Texture & Flavour \\
\hline \multicolumn{6}{|l|}{ Day 8} \\
\hline Control (fresh-cut cube) & $3.7 \pm 0.6 a b$ & $3.4 \pm 0.6 b$ & $3.6 \pm 0.9 a$ & $3.6 \pm 0.6 b$ & $3.7 \pm 0.8 a$ \\
\hline Cube & $3.8 \pm 0.5 \mathrm{ab}$ & $3.8 \pm 0.4 a$ & $3.5 \pm 0.5 a$ & $4.1 \pm 0.4 a$ & $4.1 \pm 0.4 a$ \\
\hline Parallelepiped & $3.6 \pm 0.9 a b$ & $3.5 \pm 0.7 a b$ & $3.6 \pm 0.5 a$ & $3.7 \pm 0.6 a b$ & $3.7 \pm 0.5 a$ \\
\hline Cylinder & $3.3 \pm 0.9 b$ & $3.6 \pm 0.7 a b$ & $3.5 \pm 0.5 a$ & $3.9 \pm 0.5 a b$ & $3.7 \pm 0.6 \mathrm{a}$ \\
\hline Sphere & $3.9 \pm 0.6 a$ & $3.8 \pm 0.8 a b$ & $3.6 \pm 0.5 a$ & $4.1 \pm 0.4 a$ & $3.7 \pm 0.5 a$ \\
\hline \multicolumn{6}{|l|}{ Day 10} \\
\hline Control (fresh-cut cube) & $3.9 \pm 0.7 a$ & $3.8 \pm 0.7 a$ & $3.7 \pm 0.7 a$ & $3.6 \pm 0.8 a b$ & $4.0 \pm 0.6 a$ \\
\hline Cube & $3.6 \pm 0.6 a$ & $3.9 \pm 0.5 a$ & $3.3 \pm 0.5 a$ & $3.7 \pm 0.6 a b$ & $3.8 \pm 0.6 a$ \\
\hline Parallelepiped & $3.9 \pm 0.5 a$ & $3.9 \pm 0.6 a$ & $3.6 \pm 0.5 a$ & $3.9 \pm 0.7 a$ & $4.0 \pm 0.7 a$ \\
\hline Cylinder & $3.8 \pm 0.7 a$ & $3.9 \pm 0.6 a$ & $3.6 \pm 0.6 a$ & $3.6 \pm 0.6 a b$ & $3.8 \pm 0.6 a$ \\
\hline Sphere & $3.8 \pm 0.5 a$ & $3.9 \pm 0.7 a$ & $3.4 \pm 0.5 a$ & $3.4 \pm 0.5 b$ & $3.9 \pm 0.6 a$ \\
\hline
\end{tabular}

For each day, values with different letters in the same column are significantly different $(P<0.05)$. 
Differences in L-AA content between fresh and dry weight bases could be attributed to the different moisture contents of samples during storage. Cubeshaped fresh-cut papaya retained the highest L-AA content among all cut-types throughout the 10 day shelf-life period.

The results of microbiological evaluation indicated that sphere-shaped fresh-cut papaya exhibited the lowest counts among all cut-types, as no occurrence of yeasts and moulds was observed. Although papaya parallelepipeds (length $2 \mathrm{~cm}$, width $1.4 \mathrm{~cm}$, height $1.4 \mathrm{~cm}$ ) were considered by the panellists to have the best texture in sensory evaluation, spheres received the highest score for global appreciation on day 8 of storage.

The microbiological evaluation results indicated that disinfection of whole papaya associated with storage at $4{ }^{\circ} \mathrm{C}$ allowed a shelf-life of 10 days for all cut-types studied.

It is important to note that laboratory studies may vary consideably from commercial handling and thereby affect shelf-life. Thus quality improvement at all levels of produce handling and recognition that each step or procedure is significant can have a great impact on the minimal processing of fruits and vegetables.

\section{Acknowledgement}

The authors acknowledge financial support from Project SEFOTECH.NUT (Erasmus Mundus Programme 28027-IC-6-2001-BE-ERASMUS-EPS-1).

\section{References}

1 Laurila $\mathrm{E}$ and Ahvenainen R, Minimal processing of fresh fruits and vegetables, in Fruit and Vegetable Processing, ed. by Jongen W. Woodhead Publishing, Cambridge/CRC Press, Boca Raton, FL, pp. 288-306 (2002).

2 Davey MW, Van Montagu M, Inze D, Sanmartin M, Kanellis A and Smirnoff N, Plant L-ascorbic acid: chemistry, function, metabolism, bioavailabilty and effects of processing. $\mathcal{F}$ Sci Food Agric 80:825-860 (2000).

3 Yildiz F, Initial preparation, handling, and distribution of minimally processed refrigerated fruits and vegetables, in Minimally Processed Refrigerated Fruits and Vegetables, ed. by Wiley RC. Chapman and Hall, London, pp. 15-65 (1994).

4 O'Connor-Shaw RE, Roberts R, Ford AL and Nottingham SM, Shelf life of minimally processed honeydew, kiwifruit, papaya, pineapple and cantaloupe. F Food Sci 59:1202-1206 (1994).

5 Paull RE and Chen W, Minimal processing of papaya (Carica papaya L.) and the physiology of halved fruit. Postharv Biol Technol 12:93-99 (1997).

6 Hong JH and Gross KC, Maintaining quality of freshcut tomato slices through modified atmosphere packaging and low temperature storage. [Online]. Available: http://www.nal.usda.gov/ttic/tektran/data/000011/08/ 0000110899.html [4 April 2007].

7 Rivera-Lopez J, Vazquez-Ortiz FA, Ayala-Zavala JF, SoteloMundo RR and Gonzalez-Aguilar GA, Cutting shape and storage temperature affect overall quality of fresh-cut papaya cv. 'Maradol'. F Food Sci 70:S482-S489 (2005).

8 Teixeira GHA, Durigan JF, Mattiuz B and Rossi Jr OD, Fresh cut of 'Formosa' papaya. [Online]. Available: http://www.scielo.br/scielo.php?script=sci_arttext\&pid= S0101-20612001000100011 [29 November 2007].
9 Watada AE, [Online]. Available: http://findarticles.com/ p/articles/mi_m3741/is_n1_v45/ai_19193499/pg_2 [2 December 2007].

10 Stanley D, Cut-ups! Fresh-cut produce. [Online]. Available: http://findarticles.com/p/articles/mi_m3741/is_n1_v45/ ai_19193499/pg_1 [2 December 2007].

11 Almeida RF, Martins MLL, Resende ED, Vitorazi L, Carlos LA and Pinto LKA, Influence of the refrigerating temperature on the chemical characteristics of the papaya fruits cv 'Golden'. Cienc Tecnol Alim 26:577-581 (2006).

12 Tapia MS, Rojas-Grau MA, Rodriguez FJ, Ramirez J, Carmona $\mathrm{A}$ and Martin-Belloso O, Alginate and gellan based edible films for probiotic coatings on fresh-cut fruits. [Online]. Available: http://lib.bioinfo.pl/auth:Ram\%C3\%ADrez,J [2 December 2007].

13 Paull RE, Effect of temperature and relative humidity on fresh commodity quality. Postharv Biol Technol 15:263-267 (1999).

14 Chonhenchob V and Singh SP, Packaging performance comparison for distribution and export of papaya fruit. Packag Technol Sci 18:125-131 (2005).

15 Karakurt Y and Huber DJ, Activities of several membrane and cell-wall hydrolases, ethylene biosynthetic enzymes, and cell wall polyuronide degradation during low-temperature storage of intact and fresh-cut papaya (Carica papaya) fruit. Postharv Biol Technol 28:219-229 (2003).

16 Beaulieu JC and Gorny JR, Fresh-cut fruits, in The Commercial Storage of Fruits, Vegetables, and Florist and Nursery Stocks (USDA Handbook 66), ed. by Gross KC, Saltveit ME and Wang CY. USDA, Washington, DC, pp. 1-49 (2001).

17 Peleg M and Gomez-Brito L, External color as a maturity index of papaya fruits. F Food Sci 39:701-703 (1974).

18 Wiley RC (ed.), Minimally Processed Refrigerated Fruits and Vegetables. Chapman and Hall, London, pp. 10-11 (1994).

19 Subcommittee on Microbiological Criteria, Committee on Food Protection, Food and Nutrition Board and National Research Council, An Evaluation of the Role of Microbiological Criteria for Foods and Food Ingredients. National Academy Press, Washington, DC (1985).

20 Chauhan OP, Raju PS, Shylaja R, Dasgupta DK and Bawa AS, Synergistic effects of modified atmosphere and minimal processing on the keeping quality of pre-cut papaya (Carica papaya L.). F Hort Sci Biotechnol 81:903-909 (2006).

21 Francis FJ, Colour quality evaluation of horticultural crops. HortScience 15:58-59 (1980).

22 ISO, Microbiology of Food and Animal Feeding Stuffs - Horizontal Method for the Enumeration of Microorganisms - Colony-count Technique at $30^{\circ} \mathrm{C}$. ISO 4833 (2003).

23 IPQ, Microbiologia Alimentar. Contagem de Bolores e Leveduras. Parte 1: Incubação a $25^{\circ} \mathrm{C}$. NP 3277-1 (1987).

24 ISO, Microbiology of Food and Animal Feeding Stuffs - Horizontal Method for the Enumeration of Mesophilic Lactic Acid Bacteria - Colony-count Technique at 30 degrees C. ISO 15214 (1998).

25 IPQ, Microbiologia Alimentar. Regras Gerais para Pesquisa de Escherichia coli. NP 2308 (1986).

26 Rocha AMCN, Ferreira JFFC, Silva AMM, Almeida GN and Morais AMMB, Quality of grated carrot (var. Nantes) packed under vacuum. I Sci Food Agric 87:447-451 (2007).

27 Toivonen PMA and Brummel DA, Biochemical bases of appearance and texture changes in fresh-cut fruit and vegetables. Postharv Biol Technol 9:4-18 (2007).

28 Watada AE and Qi L, Quality of fresh-cut produce. Postharv Biol Technol 15:201-205 (1999).

29 Yaman O and Bayoindirli L, Effects of an edible coating and cold storage on shelf-life and quality of cherries. Lebensm Wiss Technol 35:146-150 (2002).

30 Fagundes GR and Yamanishi OK, Physical and chemical characteristics of fruits of papaya tree from 'Solo' group commercialized in 4 establishments in Brasilia-DF. Rev Bras Frutic 23:541-545 (2001). 
31 US Food and Drug Administration Center for Food Safety and Applied Nutrition, Approximate $\mathrm{pH}$ of foods and food products. [Online]. Available: http://www.cfsan.fda.gov/ comm/ lacf-phs.html [2 December 2007].

32 Lancashire RJ, Papaya - pawpaw. [Online]. Available: http:// wwwchem.uwimona.edu.jm:1 104/lectures/papaya.html [1 December 2007].

33 Medlicott AP, Reynolds JB and Thompson AK, Effects of temperature on the ripening of mango fruit (Mangifera indica L. var. 'Tommy Atkins'). F Sci Food Agric 37:469-474 (1986).

34 Hernandez Y, Lobo MG and Gonzalez M, Determination of vitamin $\mathrm{C}$ in tropical fruits: a comparative evaluation of methods. Food Chem 96:654-664 (2006).

35 Fernandes FAN, Rodrigues S, Gaspareto OCP and Oliviera EL, Optimization of osmotic dehydration of papaya followed by air-drying. Food Res Int 39:492-498 (2006).

36 Lenart A, Osmo-convective drying of fruits and vegetables: technology and application. Drying Technol 14:391-413 (1996).

37 Watada AE, Ko NP and Minott DA, Factors affecting quality of fresh-cut horticultural products. Postharv Biol Technol 9:115-125 (1996)

38 Wall $\mathrm{M}$, Ascorbic acid, vitamin A, and mineral composition of banana (Musa sp.) and papaya (Carica papaya) cultivars grown in Hawaii. F Food Compos Anal 19:434-445 (2006).

39 Artés-Hernández F, Rivera-Cabrera F and Kader AA, Quality retention and potential shelf-life of fresh-cut lemons as affected by cut-type and temperature. Postharv Biol Technol 43:245-254 (2007).

40 Jacxsens L, Devlieghere F and Debevere J, Predictive modeling for packaging design: equilibrium modified atmosphere packages of fresh-cut vegetables subjected to a simulated distribution chain. Int F Food Microbiol 73:331-341 (2002).

41 Jacxsens L, Devlieghere F, Ragaert P, Vanneste E and Debevere J, Relation between microbiological quality, metabolite production and sensory quality of equilibrium modified atmosphere packaged fresh-cut produce. Int $\mathcal{f}$ Food Microbiol 83:263-280 (2003).

42 Brackett RE, Microbiological consequences of minimally processed fruits and vegetables. F Food Qual 10:195-206 (1987).

43 Wiley RC, Preservation methods for minimally processed refrigerated foods and vegetables, in Minimally Processed Refrigerated Fruits and Vegetables, ed. by Wiley RC. Chapman and Hall, New York, NY, pp. 66-134 (1997).

44 Ahvenainen R, New approaches in improving the shelf life of minimally processed fruit and vegetables. Trends Food Sci Technol 7:179-186 (1996).

45 Soliva-Fortuny RC and Martin-Belloso O, New advances in extending the shelf life of fresh-cut fruits: a review. Trends Food Sci Technol 14:341-353 (2003).

46 Ergun M, Huber DJ, Jeong J and Bartz JA, Extended shelf life and quality of fresh-cut papaya derived from ripe fruit treated with the ethylene 1-methylcyclopropene. f Am Soc Hort Sci 131:97-103 (2006). 